\title{
Land Suitability Evaluation for Agricultural Cropland in Mongolia Using the Spatial MCDM Method and AHP Based GIS
}

\author{
Munkhdulam Otgonbayar', Clement Atzberger ${ }^{2}$, Jonathan Chambers', D. Amarsaikhan1, \\ Sebastian Böck ${ }^{2}$, Jargaltulga Tsogtbayar ${ }^{3}$ \\ ${ }^{1}$ Institute of Geography-Geoecology, Mongolian Academy of Sciences, Ulaanbaatar, Mongolia \\ ${ }^{2}$ Institute of Surveying, Remote Sensing and Land Information, Department of Landscape Spatial and Infrastructure Science, \\ University of Natural Resources and Life Sciences, Vienna, Austria \\ ${ }^{3}$ Eng-Geo Tech LLC, Ulaanbaatar, Mongolia \\ Email: munkhdulamo@gmail.com
}

How to cite this paper: Otgonbayar, M., Atzberger, C., Chambers, J., Amarsaikhan, D., Böck, S. and Tsogtbayar, J. (2017) Land Suitability Evaluation for Agricultural Cropland in Mongolia Using the Spatial MCDM Method and AHP Based GIS. Journal of Geoscience and Environment Protection, 5, 238-263.

https://doi.org/10.4236/gep.2017.59017

Received: August 15, 2017

Accepted: September 23, 2017

Published: September 26, 2017

Copyright (c) 2017 by authors and Scientific Research Publishing Inc. This work is licensed under the Creative Commons Attribution International License (CC BY 4.0).

http://creativecommons.org/licenses/by/4.0/

\section{(c) (i) Open Access}

\begin{abstract}
The purpose of this study was to prepare a cropland suitability map of Mongolia based on comprehensive landscape principles, including topography, soil properties, vegetation, climate and socio-economic factors. The primary goal was to create a more accurate map to estimate vegetation criteria (above ground biomass AGB), soil organic matter, soil texture, and the hydrothermal coefficient using Landsat 8 satellite imagery. The analysis used Landsat $8 \mathrm{im}$ agery from the 2016 summer season with a resolution of 30 meters, time series MODIS vegetation products (MOD13, MOD15, MOD17) averaged over 16 days from June to August 2000-2016, an SRTM DEM with a resolution of 30 meters, and a field survey of measured biomass and soil data. In total, 6 main factors were classified and quality evaluation criteria were developed for 17 criteria, each with 5 levels. In this research the spatial MCDM (multi-criteria decision-making) method and AHP based GIS were applied. This was developed for each criteria layer's value by multiplying parameters for each factor obtained from the pair comparison matrix by the weight addition, and by the suitable evaluation of several criteria factors affecting cropland. General accuracy was $88 \%$, while PLS and RF regressions were $82.3 \%$ and $92.8 \%$, respectively.
\end{abstract}

\section{Keywords}

Land Suitability, MCDM, Boolean and Fuzzy Analysis, AHP, RF and PLS Regression 


\section{Introduction}

Science-based agricultural production has been developing intensively in Mongolia since 1960 [1]. Between 1960 and 1989 the total sown area increased from 267.1 to 846.1 thousand hectares. From 1989 the total sown area fell, reaching 165.0 thousand hectares in 2006 [2]. The sown areas rose steadily by 440.6 thousand hectares between the years 2006 and 2016. However, cropland remains 405.5 thousand hectares less than in 1989. In this same time period, the total population increased 3.19 times while the amount of sown area declined by half as compared with the population growth. There is a significant difference in vegetable consumption between the urban and rural population. Urban population vegetable consumption is double that of the rural population [3].

In 1960, 40.2\% of the total population lived in settled areas. This increased to $66.4 \%$ by 2016 . Population increase coupled with consumption increase resulted in an intensified demand for food. On the other hand, agricultural products, especially wheat and potato production, increased as a result of the national government crop development program. Nowadays, potato and wheat consumption needs can be fulfilled by domestic production. However, of the total vegetable consumption (not including potato), $40 \%$ - 45\% were imported [4].

The main vegetables imports (onion, garlic, cabbage, turnips and other root seed vegetables) increased from 5438.4 tons in 1995 to 64,107 tons in 2016, an increase of 11.7 times. Of these, 96\% - 99\% were imported from China. Mongolia remains strongly dependent on food security from neighboring countries. In addition, soils of currently cultivated areas are degrading. The country is facing challenges (especially local governments and community groups) to identify new crop areas with enough capacity for cultivation.

We have previously studied this topic: "Land suitability evaluation for cropland based on GIS between 2014 and 2016", was funded by the Mongolian Agency of Administration of Land Affairs, Geodesy and Cartography. In our preliminary study we used small and medium scale digital thematic maps to analyze and assess land suitability for cropland. During the study it was recognized that there was a need to improve the accuracy of input data using high-resolution satellite imagery for future research [5].

Geographic information system (GIS) and remote sensing (RS) techniques have been broadly used in agricultural studies. Remote sensing can provide a timely and accurate picture of the agricultural sector, as it is very suitable for gathering information over large areas with frequency and regularity [6]. The derived information is used for qualitative and quantitative analysis within near real-time production forecasts as well as for the anticipation of food security problems within the framework of monitoring agriculture [7].

\section{Objectives}

The purpose of this study is to identify new crop areas with enough capacity for cultivation across the entirety of Mongolia. The specific objectives are as follows: 
- Identify a methodology for land suitability evaluation for agricultural cropland.

- Develop criteria parameters for land suitability evaluation for agricultural cropland.

- Prepare more accurate input data using high-resolution satellite imagery.

- Use the spatial MCDM method and the AHP GIS for land suitability evaluation for agricultural cropland.

\section{Methods}

A combination of Boolean and Fuzzy logic theory, the spatial multi-criteria decision-making method, the analytical hierarchical process (AHP), expert knowledge analysis, random forest (RF) and partial least square (PLS) regression were used.

The study's general procedure for land suitability evaluation had several phases (Figure 1). The first phase was to define the objectives. The second phase was to select criteria, for which there are two kinds of factors and constraints [8]. The third phase was standardization of the criteria; the fourth phase was assessing the ranking and weights of the criteria; the fifth phase was to overlap the map layers; the sixth phase was accuracy assessment.

\subsection{Creation of Constraint Map Using Boolean Logic Theory}

Constraints can be expressed in the form of a Boolean (logical) [8]. Boolean logic can have only two outcomes, true (1) or false (0). A constraint factor is a discrete

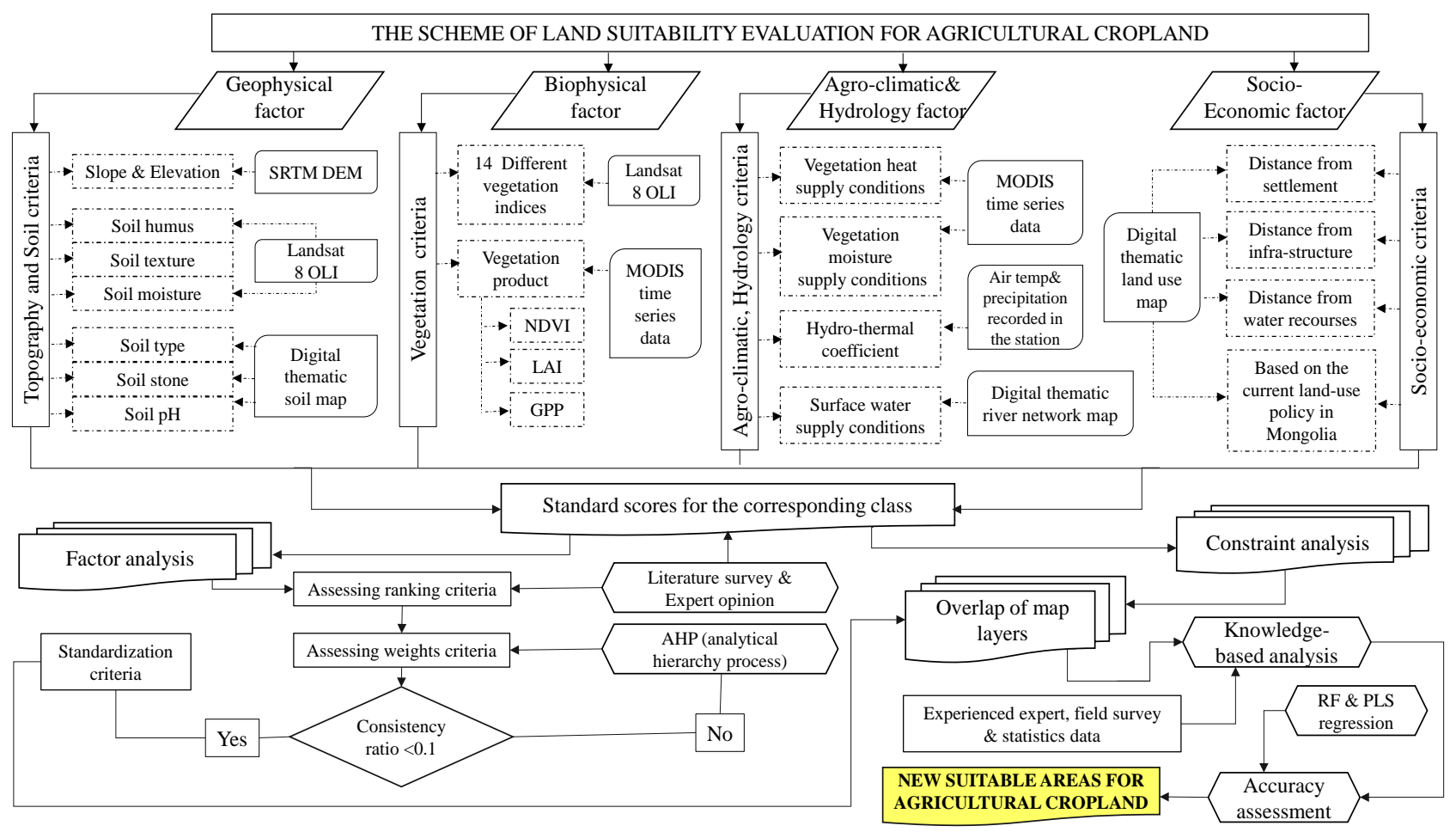

Figure 1. The approach of land suitability evaluation for agricultural cropland. 
metric that can represent a true or false condition [9]. Zero values are prohibited conditions, and 1 values are permitted conditions. Constraints in this particular study often include legal restrictions. These are current land-use policy restrictions. Condition assessments and prohibitions can be factors as well.

The Boolean logic method must assume there is a definite cut-off point, because there is no flexibility for assessing real uncertainty [10]. Boolean logic can't be used when environmental and socio-economic factors are imprecise and incomplete. Under uncertain situations, fuzzy (probabilistic) logic comes in handy [11].

\subsection{Creation of Factor Map Using Spatial Multi-Criteria Decision-Making (MCDM) Method}

A factor is a criterion that can determine the suitability of specific outcomes for activities under consideration [8]. In this study, the spatial MCDM method was used in the creation of factor maps. Suitability levels for each of the factors were defined; these levels were used as a base to generate the factor maps (one for each factor [12]. Land suitability evaluation is expressed by qualitative and quantitative parameters.

In this section a combination of the spatial MCDM-, and the Fuzzy method was used. The main objective of land suitability analysis is to select the most optimal areas for a specific purpose. Land suitability analysis is a multi-criteria decision-making process [11]. Land suitability analysis is an interdisciplinary approach that includes information from different factors such as environmental and socio-economic. A main advantage of the MCDM procedure is the decision rule relationship between the input and output map. The MCDM method is divided into 4 groups and 7 classes [13].

- Multi-attribute and multi-objective decision making methods based on an objective or attribute.

- Individual and group decision making methods based on the number of people involved in the decision making process.

- Decision making under certainty and uncertainty methods based on the situation under which decision-making is being done and the nature of the criteria.

- Spatial MCDM based on spatial data.

From these, multi-attribute, multi-objective and spatial multi-criteria decision-making methods have been widely used in land-use suitability analysis. The multi-objective methods are based on mathematical programming models, and the multi-attribute methods are data oriented [14]. Spatial MCDM is a process where geographical data can be combined and transformed into a decision [11].

The main purpose of the spatial MCDM is to solve spatial decision-making problems originating from multiple criteria. The integration of spatial MCDM techniques with GIS has considerably advanced conventional map overlay approaches with regard to land-use suitability analysis [11] [13] [15] [16] [17] [18]. Land suitability analysis involves the incorporation of expert knowledge at vari- 
ous levels of decision-making. Experts however, cannot be certain all the time, there is still uncertainty and imprecision.

The MCDM method contains many different theories on how to improve the algorithm for processing imprecise or uncertain information, such as Fuzzy set theory, ELECTRE, PROMOTHEE, MAUT, and Random set theory. Many studies have recommended as such [8] [19]-[24]. The fuzzy set theory technique is one of the most commonly used techniques for improving upon imprecise, incomplete and vague information [25]. Fuzzy logic is like Boolean logic but more fuzzy. Mathematician Lofti Zadeh presented fuzzy set theory in 1965, illustrating a mathematically meaningful method to quantify the degree of uncertainty and imprecision of non-discrete data [26]. The main point was that fuzzy data are obtained using an array of fuzzy membership functions with values that range from "0" to "1" [27].

\subsection{Standardization of Criteria}

All criteria used in the analysis were measured with different measurement values. Different values of criteria needed to be transformed into common values [28]. In order to implement this objective, we used a criteria standardization procedure. We used a simple linear scaling equation based on the fuzzy set method.

$$
E_{i}=\frac{X_{i}-X_{\min }}{X_{\max }-X_{\text {min }}}
$$

where: $E_{i}$ is value of standardized in pixel $i, X_{\min }$ is the minimum value criteria, $X_{\max }$ is the maximum value.

\subsection{Assessing Ranking and Weights of Criteria}

In land suitability analysis there must be an evaluation that ranks the relative importance of the criteria. In this evaluation many different factors such as geophysical, biophysical, climate, and socio-economic were ranked. We ranked each criterion based on conclusions from literature from professional experts. Next, came the important step of determining the weighting values for each criterion. There are many different approaches for assessing the weight of criteria based on MCDM techniques such as ELECTRE-TRI [29], ordered weighted averaging [30], compromise programming [31], analytical hierarchy process (AHP) [32] [33] [34] and Fuzzy AHP [11] [24]. Sensitivity analysis [35] includes 3 different approaches such as one-dimensional weights, random weights and selected weights [36]. From these, the most widely used method in spatial multi-criteria decision analysis for land suitability evaluation is the GIS-based AHP because it calculates weight values associated with criteria maps through a pairwise comparison matrix. Moreover, the weighting values of each of the criteria can be compared against each other with an index consistency. AHP has been calculated by weighting values of the criteria, and it is expressed with the following equation. 


$$
W_{i j}=\frac{\sum X(i j)}{n}
$$

where: $X_{i j}$-normalized value of a pairwise comparison matrix; $n$-the order of the matrix; $W_{i j}$-weight of the criteria.

The consistency ratio (CR) indicates the probability, and that the matrix ratings were randomly generated. The consistency of the pairwise comparison matrix is expressed by the consistency ration index. When the CR exceed 0.1 the weighting value is disagreeable, and when the index value is estimated below 0.1, the weighting value is agreeable.

$$
\mathrm{CR}=\frac{\mathrm{CI}}{\mathrm{RI}}
$$

where: $\mathrm{CI}$-consistency index; $\mathrm{RI}$-random index; $\mathrm{CR}$ - consistency ratio.

Herein, calculating the consistency index was applied to the following common equation.

$$
\mathrm{CI}=\frac{\lambda_{\max }-n}{n-1}
$$

where: $\mathrm{CI}-$ consistency index; $\lambda_{\max }-$ maximum eigen value, and $n$ is the order of the matrix

\subsection{Overlap of Map Layers}

After describing weights values of the criteria concerning their importance for land suitability analysis, all criteria maps have been overlaid using suitability index. The formula used for calculating the suitability index of each layer was as follows:

$$
S_{i}=\sum X_{i} * W_{i}
$$

where,

$$
\begin{aligned}
& X_{i} \text {-values of the each criterion, } \\
& W_{i} \text { - weight values of the each criterion, } \\
& S_{i} \text { - suitability index. }
\end{aligned}
$$

\subsection{Accuracy Assessment}

Accuracy assessments for random forest (RF) and partial least square (PLS) regression were calculated and compared with field survey biomass and soil archive data obtained from the Information and Research Institute of Hydrology, Meteorology and Environment. The Institute is authorized to provide qualified nationwide data sets.

\section{Study Area}

The study area covers the entirety $\left(1566.6 \times 10^{3}\right.$ square kilometers) of Mongolia (Figure 2). Mongolia is comprised of $73 \%$ agricultural land, $0.5 \%$ villages and other settlements, $0.35 \%$ land under roads and networks, $9.2 \%$ forest and forest resources, $0.4 \%$ water and water resources and $16.1 \%$ land for special needs. 


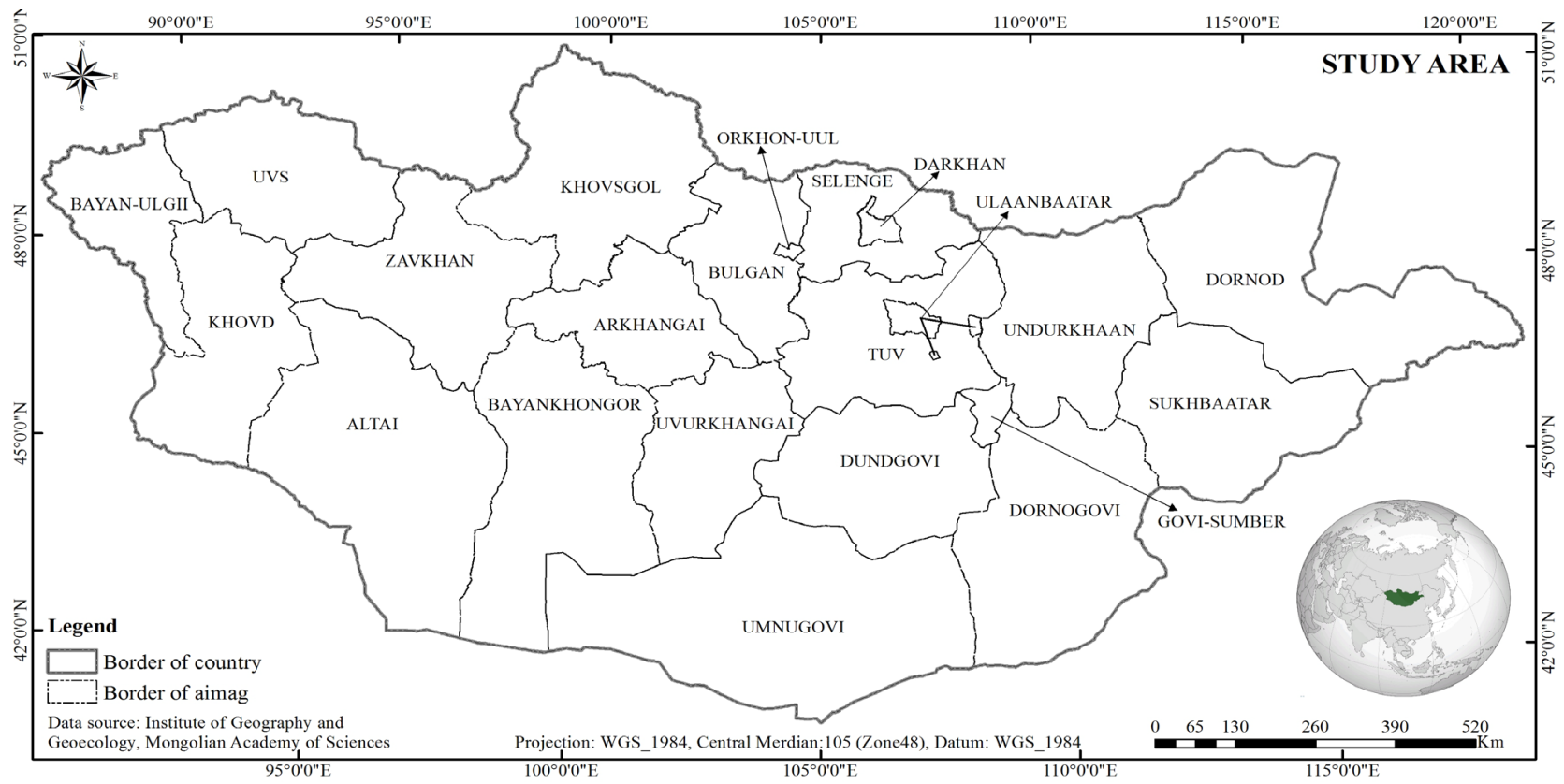

Figure 2. Location of the study area.

There are 21 administrative units, a population of over 3.0 million, and more than 52 million livestock in the country. The country is located in the continental temperate zone with an arid climate and variable topography. Annual average precipitation is $50-500 \mathrm{~mm}$, annual average air temperature is $-1.27^{\circ} \mathrm{C}$ $2.22^{\circ} \mathrm{C}$, and average wind speed is $5-10 \mathrm{~m} / \mathrm{s}$.

\section{Data Used and Pre-Processing}

\subsection{Data Used}

The main goal of the study was to create more accurate input maps using satellite imagery and ground measurement data such as soil humus, soil texture, soil permeability, agro-climate condition, and hydrothermal in land suitability evaluation for agricultural cropland. In order to implement this three different datasets were used; satellite data, biomass data from field surveys, and field survey soil data (Table 1). In the subsequent analysis Random forest (RF) and Partial least square (PLS) regressions were used.

\subsection{Data Pre-Processing}

The first step in processing the Landsat 8 satellite imagery was to calibrate the radiometric and atmospheric correction. Radiometric calibration is used to calibrate radiance, reflectance or brightness temperature in imagery analysis. Atmospheric correction was applied to eliminate the impact of the atmosphere, such as the amount of water vapor, distribution of aerosols, and scene visibility. In other words, eliminating the impact of the atmosphere is a pre-processing step for analyzing images of surface reflectance. Atmospheric correction was implemented in the QGIS 2.18 SCP plugin, parameterized with a tropical atmos- 
Table 1. Used data.

\begin{tabular}{|c|c|c|c|c|c|}
\hline Type of data & Path/Row & Bands & Resolution, $\mathrm{m}$ & Date & Source \\
\hline \multicolumn{6}{|c|}{ Raster data } \\
\hline Landsat 8 & $\begin{array}{c}123-143 / \\
24-31\end{array}$ & $2-7$ & 30 & $\begin{array}{l}\text { Between on } 1^{\text {st }} \\
\text { June and } 31^{\text {st }} \\
\text { August, } 2016\end{array}$ & $\begin{array}{c}\text { www.glovis.usgs.gov } \\
\text { http://earthexplorer.gov }\end{array}$ \\
\hline SRTM DEM & $\begin{array}{c}123-143 / \\
24-31\end{array}$ & 1 & 30,90 & Version 5.0 & http://earthexplorer.gov \\
\hline GLC product & - & LC type & 30 & $03^{\text {rd }}$ July 2014 & http://www.glcn.org/databases/ \\
\hline \multirow{3}{*}{$\begin{array}{l}\text { MODIS } \\
\text { product }\end{array}$} & & MOD13 & 250 & Average 16 & \multirow{3}{*}{$\underline{\text { www.ipdaac.usgs.gov }}$} \\
\hline & $\begin{array}{c}23-25 / \\
03-04\end{array}$ & MOD15 & 500 & $\begin{array}{l}\text { days, from } 1^{\text {st }} \\
\text { June to } 31^{\text {st }}\end{array}$ & \\
\hline & $26 / 04$ & MOD17 & 1000 & $\begin{array}{c}\text { August } \\
2000-2016\end{array}$ & \\
\hline \multicolumn{6}{|c|}{ Field data } \\
\hline Biomass data & 969 sites & 1 hectare & $\begin{array}{c}100 \\
\text { centner/ha }\end{array}$ & $\begin{array}{l}1^{\text {st }} \text { August } \\
2016\end{array}$ & \multirow{2}{*}{ IRIMHE } \\
\hline $\begin{array}{l}\text { Field survey } \\
\text { soil data }\end{array}$ & 137 sites & 501 plots & $1^{*} 1$ & 2013-2016 & \\
\hline \multicolumn{6}{|c|}{ Vector data } \\
\hline Land use data & - & - & Scale & - & \multirow{2}{*}{ AALAGC } \\
\hline River Network & - & - & $1: 100,000$ & - & \\
\hline $\begin{array}{l}\text { Soil humus, } \\
\text { soil stone, soil } \\
\text { pH }\end{array}$ & - & - & $\begin{array}{c}\text { Scale } \\
1: 5,000,000\end{array}$ & - & $\begin{array}{c}\text { National Atlas of } \\
\text { Mongolia, 2009, } \\
\text { IGG, MAS }\end{array}$ \\
\hline $\begin{array}{c}\text { Distribution } \\
\text { permafrost }\end{array}$ & - & - & - & - & $\begin{array}{l}\text { www.eic.mn } \\
\text { IGG, MAS }\end{array}$ \\
\hline \multicolumn{3}{|c|}{$\begin{array}{l}\text { Sum of daily rainfall and mean } \\
\text { the temperature in summer season }\end{array}$} & - & - & IRIMHE \\
\hline
\end{tabular}

SRTM-Shuttle radar topographic mission; DEM-digital elevation model, MODIS-moderate-resolution imaging spectroradiometer; GLC-global land cover; LC-land cover; IGG-Institute of Geography and Geoecology; MAS-Mongolian Academy of Sciences; IRIMHE-Information and Research Institute of Meteorology, Hydrology and Environment; AALAGG-Agency of Administration of Land Affair, Geodesy and Cartography.

pheric model, a rural aerosol model, no aerosol retrieval and $40 \mathrm{~km}$ initial visibility. These were generated from the six bands of the surfaces' reflectance images. In this study 104 scenes of Landsat 8 satellite were analyzed, and the primary difficulty was the associated color balance. In order to address this we used the MOSPREP algorithm with the bundle color balancing method in PCI GEOMATICA. The bundle color balancing method applies a global adjustment of the mean and sigma of each image using a "block-bundle" method between it and each of its overlapping images, and then, using dodging points, makes smaller local adjustments between pairs of images once they have been mosaicked (www.pcigeomatics.com).

For MODIS satellite image processing the first step was to convert the input 
file format and coordinate system, and then apply the atmospheric correction. Using MRT (MODIS re-projection tools) we can read input datasets in HDFEOS, which were then converted to the UTM coordinate system with a changed file format (*.tiff). The generated surfaces' reflectance images each used atmospheric correction as implemented in the QGIS2.18 SCP plugin. All image pre-processing used QGIS 2.18, ArcMap 10.4, PCI, Geomatica, ENVI v5.1, and RStudio.

Data validations accuracy assessment RF and PLS were calculated to compare with field survey soil and biomass data. RF regression was chosen because RF is a statistical algorithm that is capable of synthesizing regression or classification functions based on discrete or continuous datasets [37]. RF and CDT regression analyses were performed in Salford predictive Modeler 8.0 software. We also used PLS regression because the main goal of PLS regression is to predict or analyze a set of dependent variables from a set of independent variables or predictors [38]. PLS can easily treat data from a large number of variables in each factor that is identified [39]. Finally, all vector data were converted to raster format and then, all raster format data were transformed to the same geographical coordinate system and spatial resolution $(30 \mathrm{~m})$. Thereafter, each criterion map was classified into five suitability classes applying the classification threshold values of each criteria and standard scores for the corresponding class obtained in Table 2.

\section{Analysis}

The analysis comprised of three phases; the development of criteria parameters in land suitability evaluation for agricultural cropland; the preparation of more accurate input data using high-resolution satellite image, and an integrated evaluation.

\subsection{Develop Criteria Parameters for Land Suitability Evaluation for Agricultural Cropland}

6 main factors and 17 criteria for land suitability evaluation for agricultural cropland were selected. A criteria evaluation schema was then developed based on our own, and other countries practices, literature and expert knowledge (Table 2, Table 3). The criteria evaluation were divided into two types, multi-variables (factor) and constraint criteria parameters.

A constraint is restraint criteria and it serves to limit the alternative. The constraint can also be often represented the legal restriction. That will be the decision based on the current land-use policy. It can apply for land use constraints condition assessment such as determined by the sum of factors prohibiting the use. In this study, 9 constraints have been chosen and there are obtained range values 0 and 1 . The land use constraints condition assessment determined by the sum of factors prohibiting the use. The constraint factor assessment of land use is true or false condition represent. Zero value is impossible, and 1 value is possible. 
Table 2. Evaluation of the multi-variable (factor) criteria parameters.

\begin{tabular}{|c|c|c|c|c|c|c|c|}
\hline \multirow[b]{2}{*}{ Factor } & \multirow[b]{2}{*}{ Criteria } & \multirow[b]{2}{*}{ Unit } & \multicolumn{5}{|c|}{ Standard scores for the corresponding class } \\
\hline & & & $\begin{array}{c}\text { Highly } \\
\text { suitable } \\
\text { (5 scores) }\end{array}$ & $\begin{array}{l}\text { Suitable } \\
\text { (4 scores) }\end{array}$ & $\begin{array}{l}\text { Moderately } \\
\text { suitable } \\
\text { (3 scores) }\end{array}$ & $\begin{array}{l}\text { Unsuitable } \\
\text { (2 scores) }\end{array}$ & $\begin{array}{c}\text { Highly } \\
\text { unsuitable } \\
\text { (1 score) }\end{array}$ \\
\hline \multirow{4}{*}{ Topography } & Slope & Degree & $<3$ & $3-6$ & $6-9$ & $9-12$ & $>12$ \\
\hline & Elevation & Meter & $<1000$ & $1000-1500$ & $1500-2000$ & $2000-3500$ & $>3500$ \\
\hline & Soil humus & (\%) & $>4$ & $3-3.9$ & $2-2.9$ & $1-1.9$ & $<0.9$ \\
\hline & Depth soil humus & $(\mathrm{cm})$ & $>20.1$ & $15.1-20$ & $10.1-15$ & $5.1-10$ & $<5$ \\
\hline \multirow[t]{5}{*}{ Soil } & Soil texture & - & $\begin{array}{l}\text { Light clay } \\
(21-30), \\
\text { Sandy } \\
(10-20)\end{array}$ & $\begin{array}{l}\text { Mid-siltstone } \\
\quad(31-45)\end{array}$ & Sand $(<10)$ & $\begin{array}{l}\text { Heavy clay } \\
(45-60)\end{array}$ & Clay $(>60)$ \\
\hline & $\mathrm{nH}$ & & 6570 & $7.1-7.5$ & $7.6-8$ & $8.5-9$ & $>9$ \\
\hline & pH & - & $0.5-7.0$ & $6.1-6.5$ & $5.6-6.0$ & $5.1-5.5$ & $<5$ \\
\hline & Soil stone & $\%$ & $<5.0$ & $6-20$ & $21-35$ & $36-50$ & $>50$ \\
\hline & $\begin{array}{c}\text { Estimated soil } \\
\text { organic C }\end{array}$ & - & $>0.50$ & $0.35-0.50$ & $0.25-0.35$ & $0.15-0.25$ & $<0.15$ \\
\hline \multirow[t]{5}{*}{ Vegetation } & Estimated AGB & $\%$ & $>75$ & $55-75$ & $30-55$ & $10-30$ & $<10$ \\
\hline & NDVI & - & $>0.50$ & $0.35-0.50$ & $0.25-0.35$ & $0.15-0.25$ & $<0.15$ \\
\hline & LAI (MODIS) & $\begin{array}{c}\mathrm{m}^{2} \text { plant } / \mathrm{m}^{2} \\
\text { ground }\end{array}$ & $>60$ & $40-60$ & $20-40$ & $10-20$ & $<10$ \\
\hline & GPP (MODIS) & $\mathrm{kg} \mathrm{C} / \mathrm{m}^{2}$ & $>0.035$ & $0.02-0.035$ & $0.01-0.02$ & $0-0.01$ & $3.0-3.27$ \\
\hline & $\begin{array}{l}\text { Mean temperature } \\
\text { summer season }\end{array}$ & $\left({ }^{\circ} \mathrm{C}\right)$ & $19-22$ & $15-19$ & $>22$ & $13-15$ & $<13$ \\
\hline \multirow[t]{4}{*}{ Climate } & $\begin{array}{l}\text { Sum of rainfall } \\
\text { summer season }\end{array}$ & $(\mathrm{mm})$ & $>200.1$ & $150.1-200$ & $100.1-150$ & $50.1-100$ & $<50$ \\
\hline & Estimated & & & & & & \\
\hline & $\begin{array}{l}\text { Hydro-Thermal } \\
\text { coefficient }\end{array}$ & - & $1.5-2.0$ & $1.0-1.5$ & $0.5-1.0$ & $>2.0$ & $<0.5$ \\
\hline & River density & $\mathrm{km} / \mathrm{km}^{2}$ & $>0.4$ & $0.2-0.4$ & $0.1-0.2$ & $0.05-0.1$ & $<0.05$ \\
\hline \multirow[t]{3}{*}{ Hydrology } & $\begin{array}{l}\text { Permafrost } \\
\text { distribution }\end{array}$ & - & $\begin{array}{c}\text { Region of } \\
\text { seasonal freezing }\end{array}$ & $\begin{array}{l}\text { Sporadic \& } \\
\text { Prelatic }\end{array}$ & Island & Dis-continuous & Continuous \\
\hline & Water index & - & $>0.50$ & $0.35-0.50$ & $0.25-0.35$ & $0.15-0.25$ & $<0.15$ \\
\hline & $\begin{array}{l}\text { Distance from } \\
\text { settlement area }\end{array}$ & $\mathrm{km}$ & $<100$ & $100-200$ & $200-400$ & $400-800$ & $>800$ \\
\hline \multirow[t]{2}{*}{ Socio-economic } & $\begin{array}{l}\text { Distance from } \\
\text { infrastructure }\end{array}$ & $\mathrm{km}$ & $<50$ & $50-100$ & $100-300$ & $300-500$ & $>500$ \\
\hline & $\begin{array}{l}\text { Distance from } \\
\text { surface water } \\
\text { resources }\end{array}$ & $\mathrm{km}$ & $<3$ & $3-6$ & $6-12$ & $12-15$ & $>15$ \\
\hline
\end{tabular}


Table 3. Evaluation of the constraint criteria parameters.

\begin{tabular}{|c|c|c|c|}
\hline \multirow[t]{2}{*}{ Constraint criteria } & \multicolumn{2}{|c|}{$\begin{array}{l}\text { Standard scores for } \\
\text { the corresponding } \\
\text { class }\end{array}$} & \multirow[t]{2}{*}{ Requirement } \\
\hline & $\begin{array}{c}\text { Prohibit } \\
\text { land }\end{array}$ & $\begin{array}{l}\text { Other } \\
\text { land }\end{array}$ & \\
\hline Forest land & 0 & 1 & $\begin{array}{c}\text { Forest land for natural resources not be } \\
\text { in used for cropland purposes }\end{array}$ \\
\hline Urban land & 0 & 1 & $\begin{array}{c}\text { Not be located in near settlement and in } \\
\text { the settlement areas }\end{array}$ \\
\hline $\begin{array}{l}\text { Roads, high-voltage } \\
\text { electricity transmission } \\
\text { network areas }\end{array}$ & 0 & 1 & $\begin{array}{l}\text { Avoid roads, high-voltage electricity } \\
\text { transmission network areas }\end{array}$ \\
\hline Cropland & 0 & 1 & Not be located cropland areas \\
\hline Mining land & 0 & 1 & Not be located mining areas \\
\hline $\begin{array}{l}\text { Historical and cultural } \\
\text { monuments areas }\end{array}$ & 0 & 1 & $\begin{array}{l}\text { Not be located historical and } \\
\text { cultural monuments areas } \\
\text { (buffer zone with } 500 \text { m radius) }\end{array}$ \\
\hline Archaeological sites & 0 & 1 & $\begin{array}{l}\text { Not be located archaeological sites } \\
\text { (buffer zone with } 500 \text { m radius) }\end{array}$ \\
\hline River, lake, ponds & 0 & 1 & $\begin{array}{c}\text { Be near to water reserve, but not in } \\
\text { buffer zone }\end{array}$ \\
\hline $\begin{array}{l}\text { Springs, wells and water } \\
\text { points }\end{array}$ & 0 & 1 & $\begin{array}{c}\text { Be near to water reserve, but not in } \\
\text { buffer zone } \\
\text { (buffer zone with } 500 \text { m radius) }\end{array}$ \\
\hline
\end{tabular}

\subsection{Prepare More Accurate Input Data Using High-Resolution Satellite Image}

Complex natural factors are nearly impossible to express by quantitative and qualitative values with 100 percent conviction. In order to improve accuracy, various analytical methods and satellite images were used. In this section we attempted to estimate vegetation parameters, soil organic matter, soil texture, soil moisture, and agro-climatic conditions for the hydrothermal coefficient using Landsat 8 image and MODIS products (MOD11, MOD13, MOD15, MOD17) that used the follow indices (Table 4).

\subsubsection{Topography Factor Analysis}

Topography is important for maintaining slope stability and is critical to the distribution of other variables at a regional and local scale (e.g. a steep terrain should not be tilled to prevent soil erosion). The factors of slope and elevation were chosen for analysis of the contribution of topography to land suitability. The analysis used STRM DEM with a spatial resolution of 30 meters, which can be inverted from the remote sensing data. This was then classified into five map classes for slope and elevation by land suitability level (Table 2). 
Table 4. Vegetation \& other indices used in this study.

\begin{tabular}{|c|c|c|c|}
\hline Vegetation index & Abbr & Formula & Reference \\
\hline $\begin{array}{l}\text { Green Normalized Difference } \\
\text { Vegetation Index }\end{array}$ & NDVI green & $\frac{(\text { NIR }- \text { Green })}{(\text { NIR }+ \text { Green })}$ & [40] \\
\hline Simple Ratio & Simple Ratio & $\frac{N I R}{\operatorname{Red}}$ & [41] \\
\hline Green Chlorophyll Index & $\mathrm{Cl}$ green & $\frac{N I R}{\operatorname{Red}}-1$ & [42] \\
\hline $\begin{array}{l}\text { Normalized Difference Vegetation } \\
\text { Index }\end{array}$ & NDVI & $\frac{(N I R-R e d)}{(N I R+R e d)}$ & [43] \\
\hline Enhanced Vegetation Index & $\mathrm{EV}_{1}$ & $2.5 * \frac{(N I R-R E D)}{(1+N I R+6 * \operatorname{Re} d-7.5 * \text { Blue })}$ & [44] \\
\hline Enhanced Vegetation Index 2 & $\mathrm{EV}_{2}$ & $2.5 * \frac{(N I R-R e d)}{(1+N I R+2.4 * R e d)}$ & [45] \\
\hline $\begin{array}{l}\text { Wide Dynamic Rage Vegetation } \\
\text { Index }\end{array}$ & WDRVI & $\frac{(\alpha * N I R-R e d)}{(\alpha * N I R+R e d)}$ & [46] \\
\hline $\begin{array}{l}\text { Green Wide Dynamic Rage } \\
\text { Vegetation Index }\end{array}$ & WDRVI green & $\frac{(\alpha * \text { NIR }- \text { Green })}{(\alpha * \text { NIR }+ \text { Green })+\frac{(1-\alpha)}{(1+\alpha)}}$ & [47] \\
\hline $\begin{array}{l}\text { Modified Soil Adjusted Vegetation } \\
\text { Index } 2\end{array}$ & MSAVI2 & $\frac{N I R+1-\sqrt{(2 * N I R+1)^{2}-8 *(N I R-R E D)}}{2}$ & [48] \\
\hline Colorations Index & CI & $\frac{(\text { Red }- \text { Green })}{(\text { Red }+ \text { Green })}$ & [49] \\
\hline Hue Index & $\mathrm{HI}$ & $\frac{(2 * \text { Red }- \text { Green }- \text { Blue })}{(\text { Green }+ \text { Blue })}$ & [50] \\
\hline Brightness Index & $\mathrm{BI}$ & $\frac{\sqrt{\text { Green }^{2}+\text { Red }^{2}+N I R^{2}}}{3}$ & [51] \\
\hline Redness Index & RI & $\frac{\text { Red }^{2}}{(\text { Blue }+ \text { Green })}$ & [52] \\
\hline Top Grain Size Index & GSI & $\frac{(\text { NIR }- \text { Blue })}{(\text { NIR }+ \text { Blue }+ \text { Green })}$ & [53] \\
\hline Normalized Difference Water Index & NDWI & $\frac{(N I R-S W I R)}{(N I R+S W I R)}$ & [54] \\
\hline Moisture Stress Index & MSI & $\frac{S W I R}{N I R}$ & [55] \\
\hline Soil Organic Carbon Concentration & SOC & $\operatorname{EXP}(a+b * \operatorname{Re} d+c *$ Green $+d *$ Blue $)$ & [56] \\
\hline MODIS (MOD13) & NDVI & & \\
\hline MODIS (MOD15) & LAI & - & www.ipdaac.usgs.gov \\
\hline MODIS (MOD17) & GPP & & \\
\hline
\end{tabular}

NIR-near infrared wavelength, Red-red wavelength, Green-green wavelength, Blue-blue wavelength, SWIR-short wavelength infrared, $\alpha$ a value of $0.3, \mathrm{a}, \mathrm{b}, \mathrm{c}$ and $\mathrm{d}$ are coefficients where $\mathrm{a}=1.71499, \mathrm{~b}=-0.01576, \mathrm{c}=0.01281, \mathrm{~d}=-0.0113$. 


\subsubsection{Vegetation Factor Analysis}

Stable natural vegetation growing areas can be represented as a habitat in areas with crop vegetation. Natural vegetation parameters can provide an additional source of information for regional agro-production use [43]. Therefore, in this study vegetation indices estimated from Landsat 8 satellite image were compared with the 969 sites' biomass data from the field survey. By comprehensively analyzing 553 sites of the biomass data, 416 sites' data were eliminated because 31 sites had no data, 21 were too biased, and another 365 sites' data depended on the temporal resolution of the Landsat 8 image.

1) Partial Least Squares (PLS) regression result

A total of 17 indices were selected to analyze the correlation between measured AGB and Landsat 8 images. There were 14 vegetation indices, 2 moisture indices and 1 soil index. PLS regression analysis was performed with SPSS software.

The strongest correlation between AGB and Landsat indices were detected in the $\mathrm{Cl}$ green (0.89), simple ratio (0.89), WDRVI (0.87), NDVI (0.84), EV1 (0.84), EV2 (0.80), and MSAVI2 (0.80) as a result of the PLS regression. Correlation between AGB and Landsat 8 indices showed 11 linear indices and 6 nonlinear indices. The general correlation between AGB and Landsat indices were defined by the result of the PLS regression at $\mathrm{R}^{2} 0.749$, RMSE 1.011. In other words, AGB from Landsat 8 satellite image was estimated at $75 \%$ confidence and a linear regression was obtained.

In the four abovementioned analyses, we obtained the 6 most important variables to evaluate $\mathrm{AGB}$, the $\mathrm{Cl}$ green, simple ratio, NDVI, $\mathrm{EV}_{2}$, WDRVI and MSAVI2. We then calculated six vegetation indices using Landsat 8 to estimate AGB across the study area. The results are shown in Table 5.

We explored the relationship between estimated AGB and MODIS time-series vegetation products (NDVI, LAI, GPP), to understand the major controls of estimated AGB. Our country on average, has a 5-month natural growing season (April to August). At about the end of April and the start of May the grass turns green. June is the primary period of grass growth. The growth slows down toward the end of August, then the grass begins to fade. Therefore, in this study the MODIS vegetation products (NDVI, LAI, and GPP) covering the period from the beginning of June to the end of August was used, ranging from the year 2000 to 2016. The performed regression analyses were used to evaluate the relationship between estimated AGB and the 17-year average MODIS vegetation products.

Table 5. The result of regression models.

\begin{tabular}{|c|c|c|c|c|}
\hline Correlation & Regression types & $\mathrm{R}^{2}$ & RMSE & MSE \\
\hline \multirow{3}{*}{$\begin{array}{l}\text { Between measured AGB and } \\
\text { estimated AGB }\end{array}$} & PLS & 0.749 & 1.021 & 1.011 \\
\hline & Random forest & 0.760 & 0.966 & 0.934 \\
\hline & CART decision tree & 0.890 & 0.668 & 0.477 \\
\hline \multicolumn{5}{|c|}{ Equation: $\begin{aligned} \mathrm{AGB}= & -0.331+0.415 * \mathrm{Cl} \text { green }+2.125 * \mathrm{NDVI}+0.415 * \text { Simple ratio } \\
& +3.860 * \mathrm{EV} 2+1.987 * \mathrm{WDRVI}+4.082 * \mathrm{MSAVI}\end{aligned}$} \\
\hline
\end{tabular}




\subsubsection{Soil Factor Analysis}

Parameters of soil properties mirror the land suitability evaluation for agricultural cropland. The spectral response of soil is influenced by a number of soil related properties such as surface condition, particle size (texture), organic matter, soil color, moisture content, iron and iron oxide content and mineralogy [57]. It is also possible to obtain soil property estimations from remotely sensed images [58]. Several studies attempted to demonstrate the relationship between soil properties and reflectance data from satellite imagery [56] [58] [59] [60] [61] [62]. From these studies, a logarithmic linear relationship for organic $\mathrm{C}$ was developed by Chen et al. This linear equation utilizes image intensity in Red, Green and Blue bands and it is widely used to evaluate soil organic properties [58] [60]. In this study, Chen's equation was used for the evaluation of the soil's organic carbon.

$$
S O C=\exp (a+b * R+c * G+d * B)
$$

$S O C$ is the surface organic $\mathrm{C} ; a, b, c$ and $d$ are curve fit parameters $(a=1.71499, b=-0.01576, c=0.01281, d=-0.0113) ; R, G$ and $B$ are wavelength ranges.

\subsubsection{Agro-Climatic Factor Analysis}

Agro-climatic factors establish a quantitative connection between vegetative processes of specific plants and their in situ atmospheric environment [63]. Mongolia has an extreme continental climate with great variation between the four seasons. It has long, cold winters and short summers, with more than $65 \%$ of its annual precipitation falling in the summer season. In the summer season, the precipitation amount and daily mean air temperature affect plant growth rate. Data from 55 meteorological stations between 1940 and 2013 show that annual precipitation averages $153 \mathrm{~mm}$ in the summer season (from June to $\mathrm{Au}$ gust), and the mean air temperature is $17.5^{\circ} \mathrm{C}$ (http://www.eic.mn/climate/). In Mongolia, the temperature threshold that allows growth and biomass production to begin is generally $+5^{\circ} \mathrm{C}$. The time period with daily temperature means at or above this threshold is approximately 150 - 165 days. One of the most important parameters to evaluate agro-climatic conditions is the hydrothermal coefficient (HTK). HTK is the sum of precipitation compared with the sum of the daily temperature in the vegetation period. In this research HTK has been estimated based on Selyaninov's formula.

$$
H T K_{i}=\frac{\sum P_{i}}{\left[0.1 * \sum T_{>X^{\circ} \mathrm{C}}\right]}
$$

$H T K_{i}-$ HydroThermal coefficient.

$\sum P$-Sum of precipitation, $\mathrm{mm}$.

$\sum T_{>X^{\circ} \mathrm{C}}$-Sum of positive daily mean temperature, ${ }^{\circ} \mathrm{C}$.

$X$ - Threshold temperature, ${ }^{\circ} \mathrm{C}$.

For the summer season, maps of total rainfall and geographical distribution of mean temperature in the study area were obtained from "Changes in event 
number and duration of rain types over Mongolia from 1981 to 2014" [64]. The maps were created in the 2010s, by the joint research efforts of the "Asia Research Center, National University of Mongolia (NUM)" and the Information and Research Institute of Meteorology, Hydrology and Environment (IRIMHE). This study used daily precipitation and temperature data recorded during the summer season (from June to August) between 1981 and 2014 from 55 meteorological stations throughout Mongolia. These maps were converted to thematic GIS layers.

\section{Results}

In this study a combination of constraint and factor analysis methods were used. There were nine constraint factors and 17 criteria factors. All constraints can be represented with values of 0 or 1 . Suitability levels between 0 and 5 were obtained for each of the factors. The levels were 5-highly suitable, 4-suitable, 3-moderately suitable, 2 - unsuitable and 1 -highly unsuitable (Table 2, Table 3).

\subsection{Result of Constraint Factor Analysis Based on Boolean Logic Theory}

Assessment of the land use constraint conditions was determined by the sum of factors restricting land usage. The constraint factor assessment of land use is represented by a true or false condition. A zero value means impossible, and a 1 value means possible. We defined the forest, urban area, roads, high-voltage electricity transmission network areas, mining areas, historical and cultural monument areas, archaeological sites, rivers, lakes, springs, wells and water points (near to water reserve, but not in buffer zone) as completely unsuitable for cropland based on current land-use policy in Mongolia. Using the weighted linear combination method all constraint factors were combined. The analysis demonstrated a $31.2 \%$ constraint factor for the entirety of Mongolia (Figure 3).

\subsection{Result of Factor Analysis Based on the Spatial MCDM Method}

A comprehensive analysis of the study area used six major factors (topography, soil, vegetation, agro-climate, hydrology and socio-economic) for land suitability evaluation at the primary level. There were a different number of criteria under each category totaling 22 at the secondary level (Table 2, column 2). In this analysis 5 factors and 17 criteria were applied. The topography factor was important for maintaining slope stability and was critical to the distribution of other variables at a local scale (e.g. a steep terrain should not be tilled to prevent soil erosion). Soil governed the type of vegetation that could grow most productively in a given area, and vegetation (e.g. its presence and health conditions) showed whether the land could be used productively. The agro-climatic factor was important because it affected the growth of vegetation and crops. The hydrology determined the amount of water available for plant growth. The role of these factors in the environment varied with land cover. Therefore, due to 


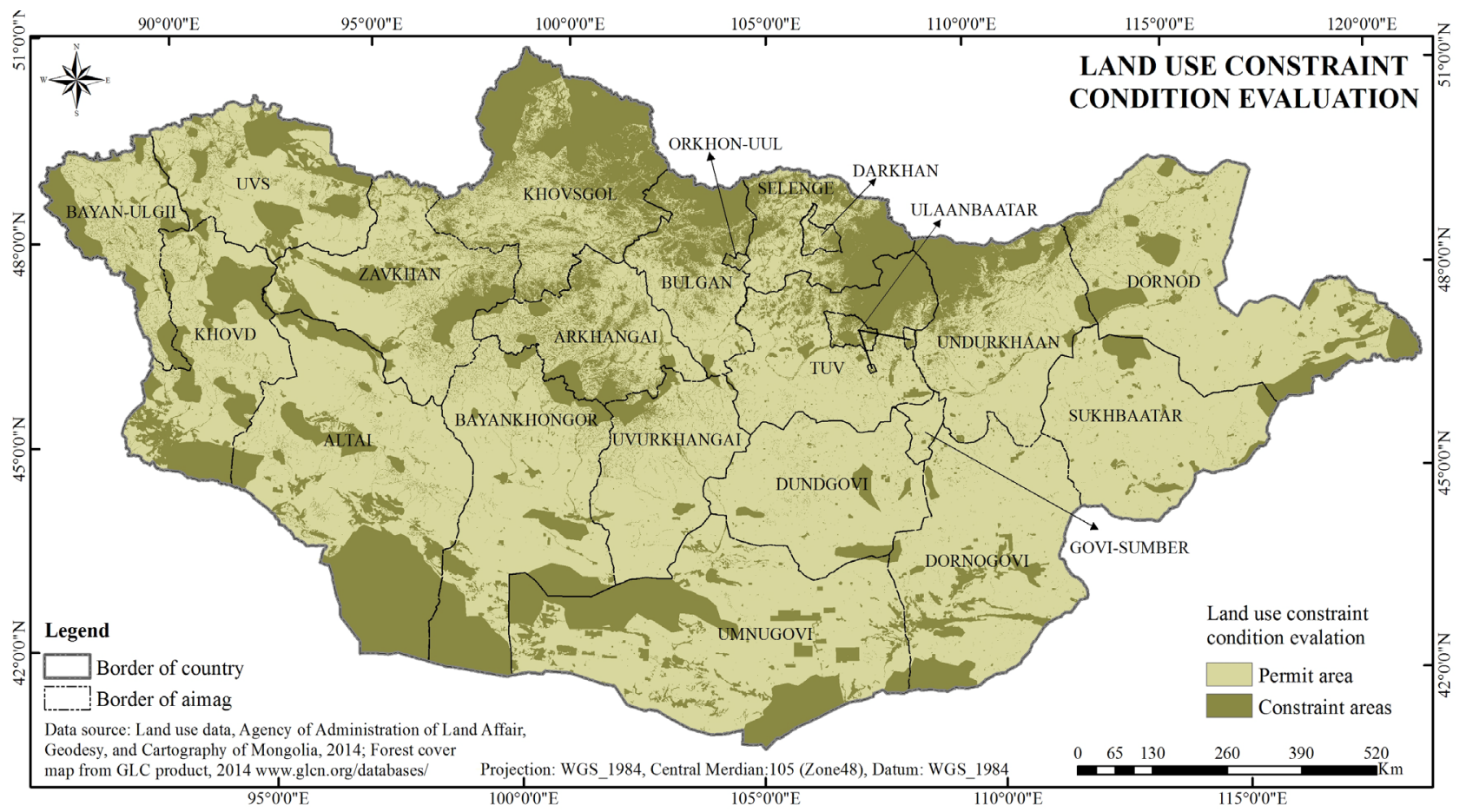

Figure 3. Land use constraint condition evaluation (Boolean map method).

changing dominance in different areas, the same environmental factors could have dissimilar influences.

Figure 4 shows the suitability value maps for 17 criteria, which represent the distribution of the suitability values within the study area using a continuous scale with values ranging from low to high.

\subsection{Results of Ranking and Weights Analysis of the Criteria Based on the AHP Method}

Table 6 shows the ranking of 17 factors based on a literature review and expert consultations, with the weights calculated using AHP based GIS. In this study we have estimated a $C R=0.089$, suggesting that there was a reasonable level of consistency in judgement.

\subsection{Result of Map Layer Overlay Analysis Based on Suitability Index}

After weighing the importance of different criteria for land suitability analysis, seventeen criteria maps were overlaid using the suitability index.

$$
\begin{aligned}
S_{i}= & 0.142 * \mathrm{~S}+0.030 * \mathrm{E}+0.142 * \mathrm{H}+0.021 * \mathrm{OC}+0.097 * \mathrm{~T}+0.014 * \mathrm{P} \\
& +0.014 * \mathrm{SS}+0.0142 * \mathrm{~A}+0.066 \mathrm{~N}+0.045 * \mathrm{~L}+0.030 * \mathrm{G}+0.097 * \mathrm{HT} \\
& +0.021 * \mathrm{SR}+0.045 \mathrm{MT}+0.069 * \mathrm{R}+0.008 * \mathrm{DP}+0.011 * \mathrm{M}
\end{aligned}
$$

The results of the analysis show that $18.8 \%$ of the area studied was highly suitable, $20.2 \%$ was suitable, $19.0 \%$ was moderately suitable, $22.6 \%$ was unsuitable, and $19.3 \%$ was highly unsuitable (Figure 5). 

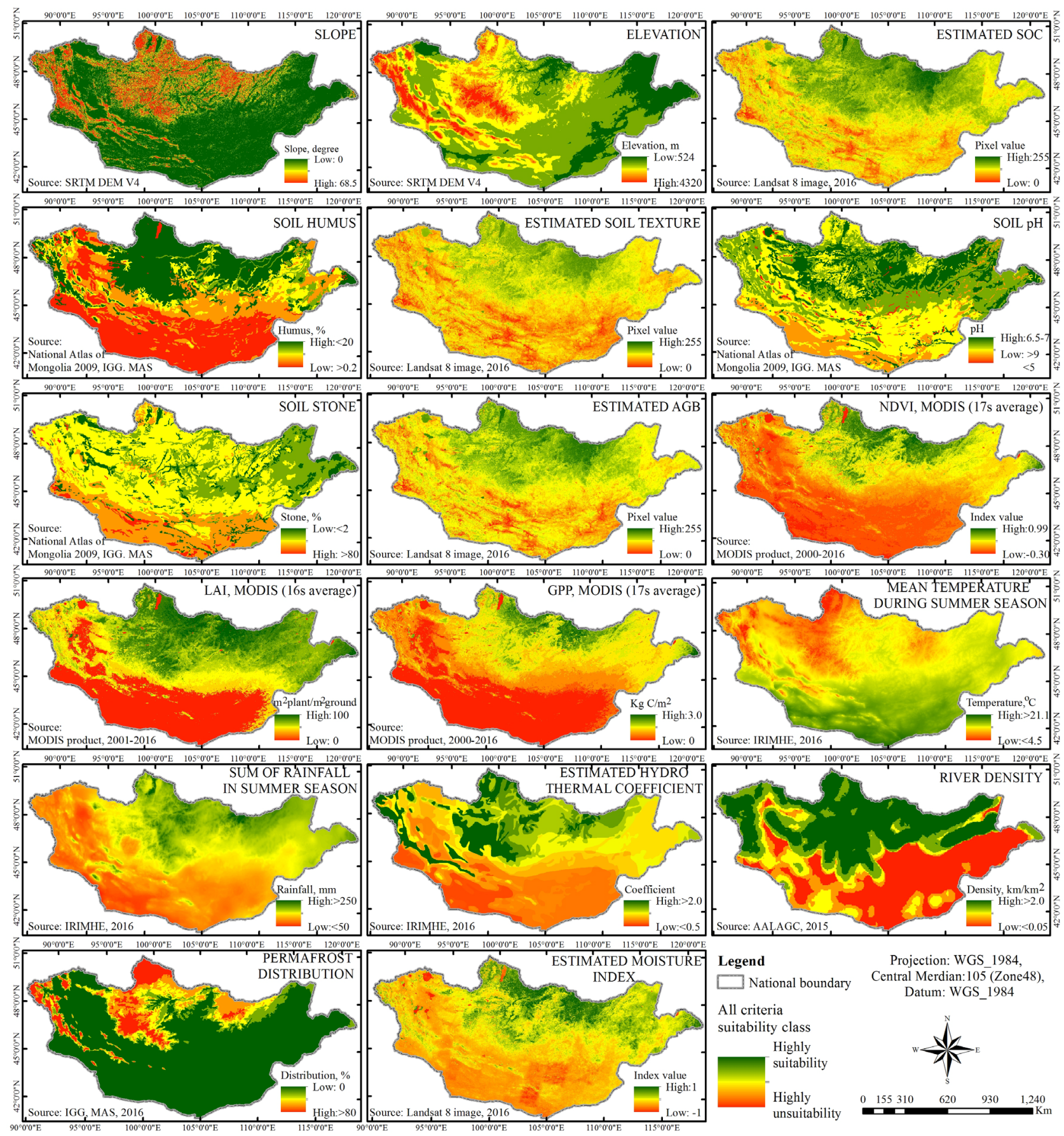

Figure 4. The main factors used in cropland suitability evaluation.

The results of the integrated assessment of constraint and factor analysis are shown in Figure 6, and Table 7. The integrated assessment shows that $10.1 \%$ of the area covered was highly suitable, $14.0 \%$ suitable, $15.5 \%$ moderately suitable, $16.3 \%$ unsuitable, $12.9 \%$ highly unsuitable and $31.2 \%$ was the constraint area.

\subsection{Accuracy Assessment}

Accuracy assessments used were the random forest (RF) and partial least square 
Table 6. Defined ranking and weights of the criteria.

\begin{tabular}{|c|c|c|c|c|c|}
\hline Factor & Weight & Criteria & Ranking & Weight & Function \\
\hline \multirow{3}{*}{ Topography } & \multirow{2}{*}{0.172} & Slope (S) & 1 & 0.142 & Linear \\
\hline & & Elevation (E) & 5 & 0.030 & Non linear \\
\hline & \multirow{5}{*}{0.288} & Humus $(\mathrm{H})$ & 1 & 0.142 & Linear \\
\hline \multirow{4}{*}{ Soil } & & $\begin{array}{c}\text { Estimated soil } \\
\text { organic C (OC) }\end{array}$ & 6 & 0.021 & Linear \\
\hline & & Texture (T) & 2 & 0.097 & Linear \\
\hline & & $\mathrm{pH}(\mathrm{P})$ & 7 & 0.014 & Non linear \\
\hline & & Stone (SS) & 7 & 0.014 & Non linear \\
\hline \multirow{4}{*}{ Vegetation } & \multirow{4}{*}{0.283} & Estimated AGB (A) & 1 & 0.142 & Linear \\
\hline & & NDVI (N) & 3 & 0.066 & Linear \\
\hline & & LAI (L) & 4 & 0.045 & Linear \\
\hline & & GPP (G) & 5 & 0.030 & Linear \\
\hline \multirow{4}{*}{ Agro-climatic } & \multirow{3}{*}{0.163} & $\begin{array}{c}\text { Estimated Hydro-Thermal } \\
\text { coefficient (HT) }\end{array}$ & 2 & 0.097 & Linear \\
\hline & & $\begin{array}{l}\text { Sum of rainfall in summer } \\
\text { season (SR) }\end{array}$ & 6 & 0.021 & Linear \\
\hline & & $\begin{array}{l}\text { Mean temperature in } \\
\text { summer season }(\mathrm{MT})\end{array}$ & 4 & 0.045 & Linear \\
\hline & \multirow{3}{*}{0.088} & River density (R) & 3 & 0.069 & Linear \\
\hline \multirow[t]{2}{*}{ Hydrology } & & $\begin{array}{l}\text { Distribution permafrost } \\
\text { (DP) }\end{array}$ & 9 & 0.008 & Non linear \\
\hline & & $\begin{array}{l}\text { Estimated moisture index } \\
(\mathrm{M})\end{array}$ & 8 & 0.011 & Linear \\
\hline
\end{tabular}

Consistency ratio (CR): 0.089 .

Table 7. Suitability classification results for cropland in Mongolia.

\begin{tabular}{|c|c|c|c|c|}
\hline \multirow{2}{*}{ Suitability classification } & \multicolumn{2}{|c|}{$\begin{array}{l}\text { Preliminary study result } \\
\text { (used thematic map) }\end{array}$} & \multicolumn{2}{|c|}{$\begin{array}{l}\text { Current study result } \\
\text { (used satellite data) }\end{array}$} \\
\hline & Area, $\mathrm{km}^{2}$ & $\%$ of total area & Area, $\mathrm{km}^{2}$ & $\%$ of total area \\
\hline Highly suitable & 83,030 & 5.30 & $157,707.5$ & 10.1 \\
\hline Suitable & 222,457 & 14.2 & $219,716.4$ & 14.0 \\
\hline Moderately suitable & 452,747 & 28.9 & $243,498.4$ & 15.5 \\
\hline Unsuitable & 249,089 & 15.9 & $255,180.5$ & 16.3 \\
\hline Highly unsuitable & 65,797 & 4.20 & $201,514.7$ & 12.9 \\
\hline Constraint area $^{*}$ & 482,513 & 30.8 & $488,982.5$ & 31.2 \\
\hline
\end{tabular}

Constraint area* is unsuitable based on current land-use policy.

(PLS) regression. The general accuracy is $88 \%$, while PLS and RF regression are $82.3 \%$ and $92.8 \%$, respectively (Graphic 1 , Graphic 2 ). The results were then compared with the current extent of sown area, and the results are shown in 


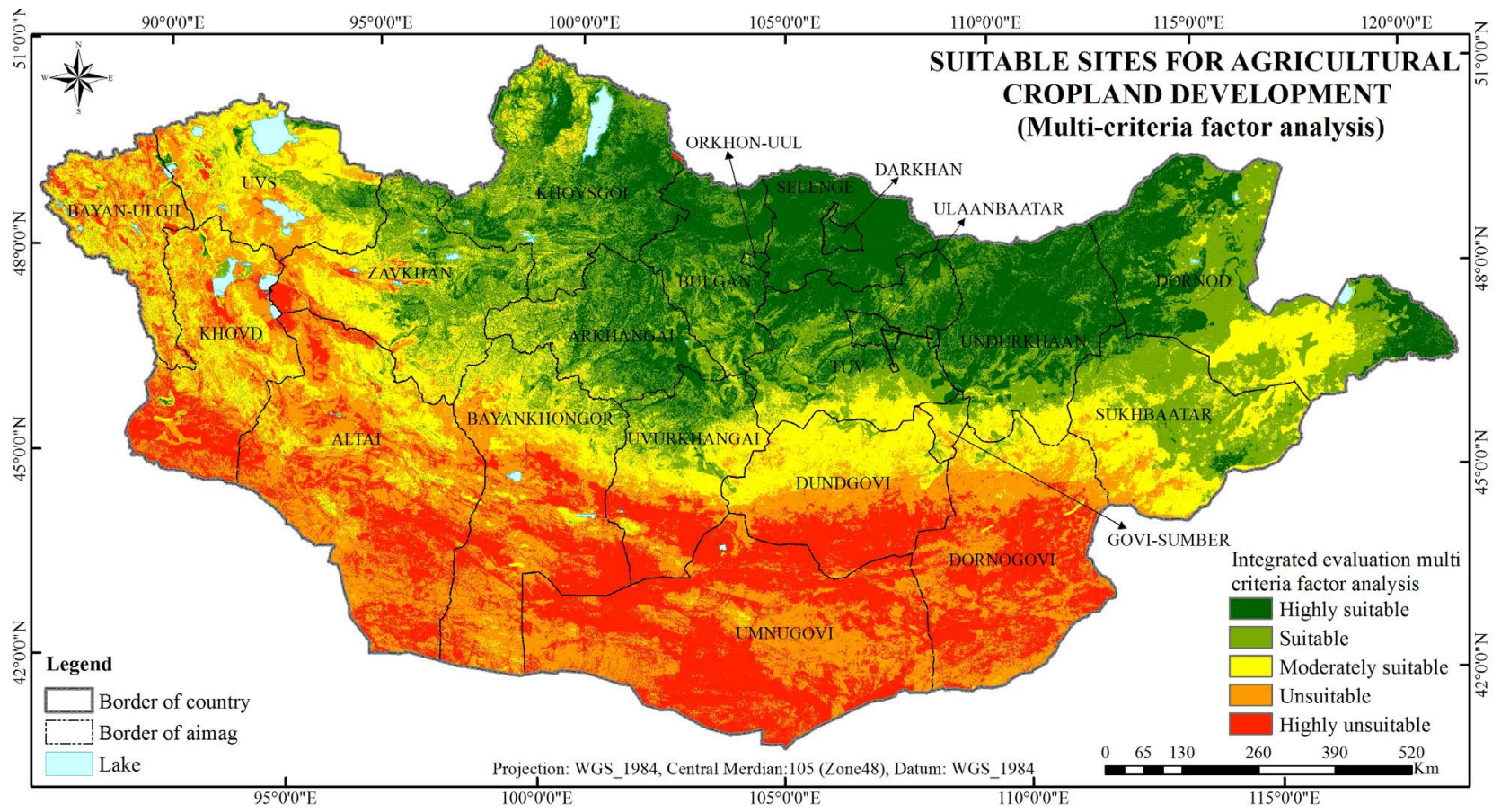

Figure 5. Suitable sites for cropland development (Multi-criteria factor analysis).

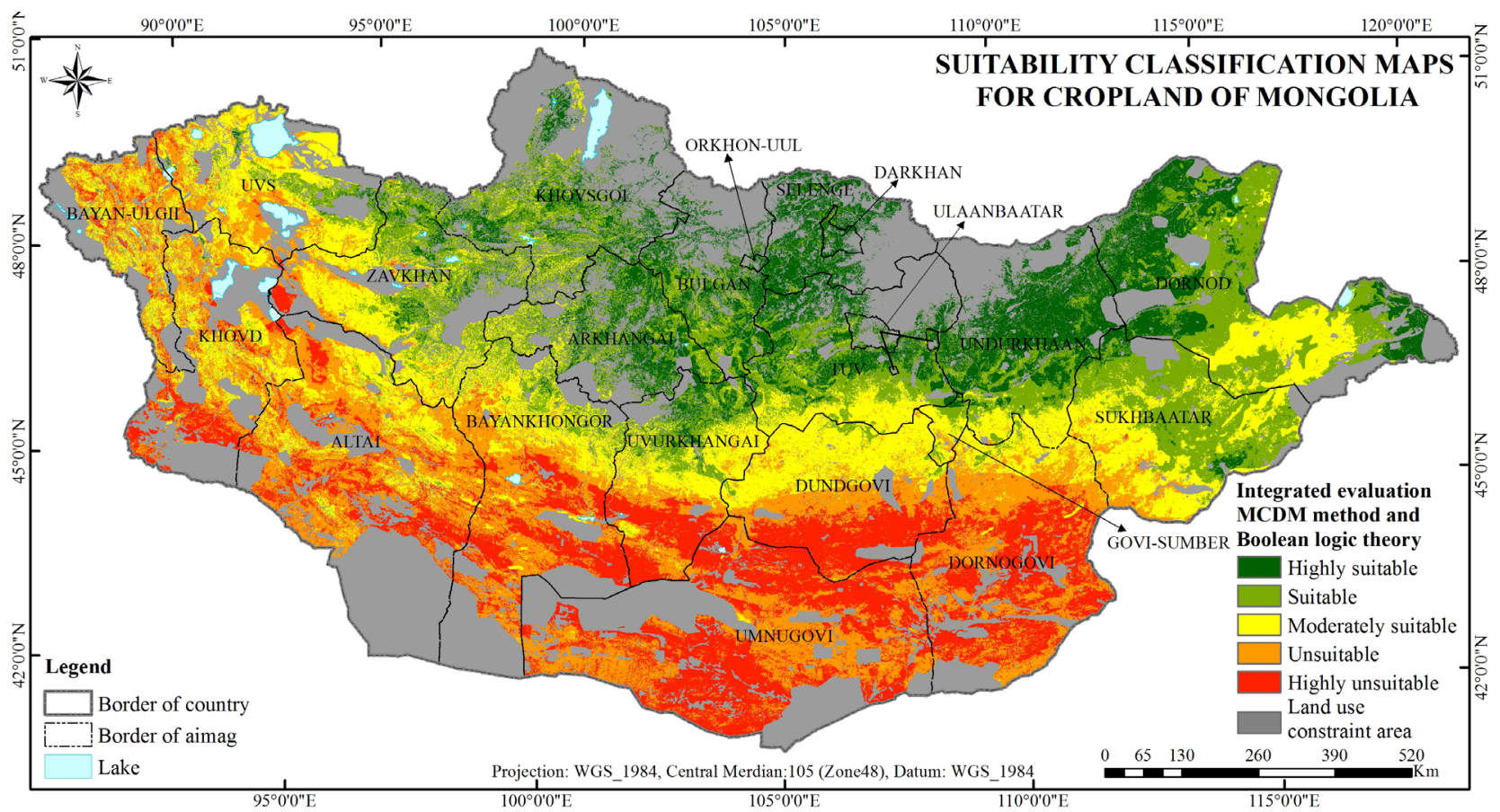

Figure 6. Suitability classification map for cropland in Mongolia.

Figure 7 and Table 8.

\section{Conclusion}

Since 1960, the method of wholesale selection was used for cropland area. This was conducted based on a few parameters such as the general condition of the 


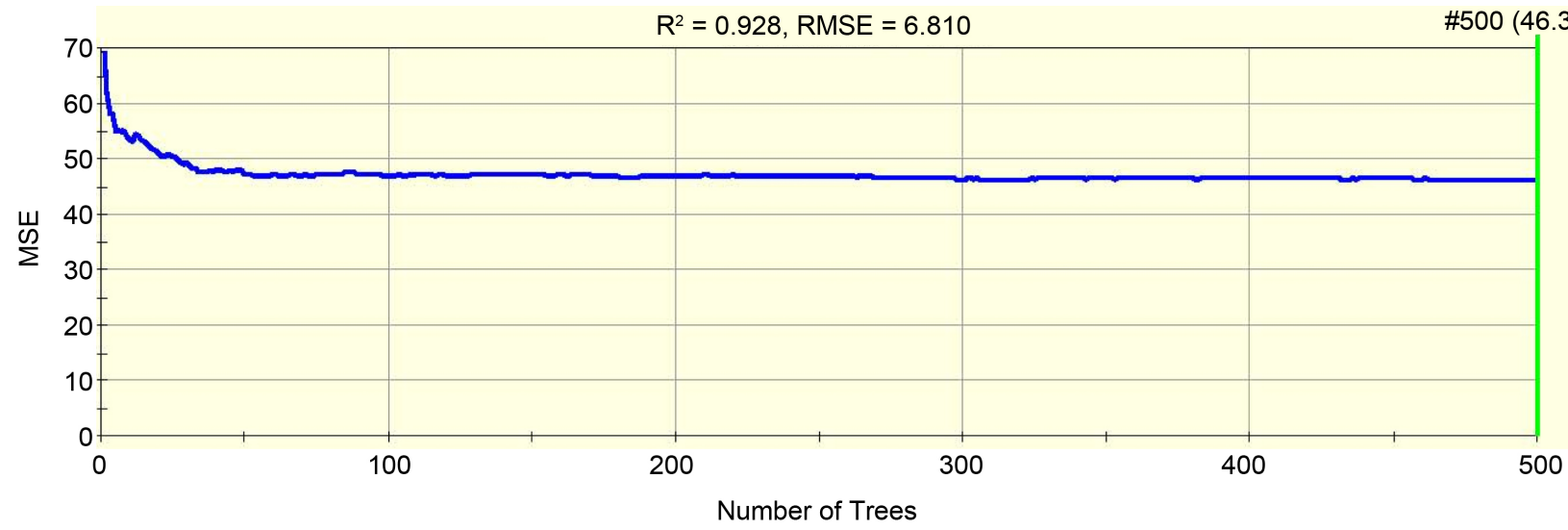

Graphic 1. The relationship between AGB and suitability classification map for cropland by RF regression results.

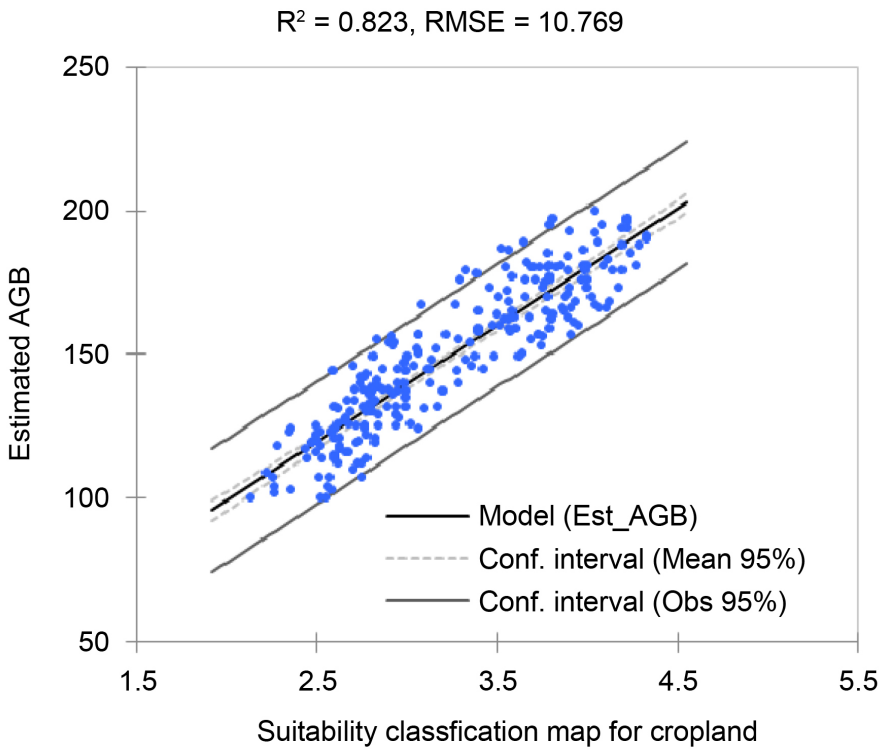

Graphic 2. The correlation between AGB and suitability classification map for cropland and PLS regression results.

weather, the natural landscape, and the content of the soil. Our study, on the other hand evaluated the extent of cropland in Mongolia, examining the results of a land suitability multi-criteria evaluation based on multiple factors such as topography, soil, vegetation, agro-climatic, hydrology and constraints. Integrated assessment of constraint and factor analyses showed that $10.1 \%$ of the study area is highly suitable, $14.0 \%$ suitable, $15.5 \%$ moderately suitable, $16.3 \%$ unsuitable, $12.9 \%$ highly unsuitable for cropland, with $31.2 \%$ as the constraint area. General accuracy was 0.88 , while PLS and RF regressions were $82.3 \%$ and $92.8 \%$, respectively. As shown in the results land suitability evaluation for cropland is possible using GIS and remote sensing technology based on a combination of multi-criteria decision output and matrix. There is now the potential to evaluate other regions of Mongolia. The abovementioned method of land suitability evaluation for cropland can be used to save time for land management, 


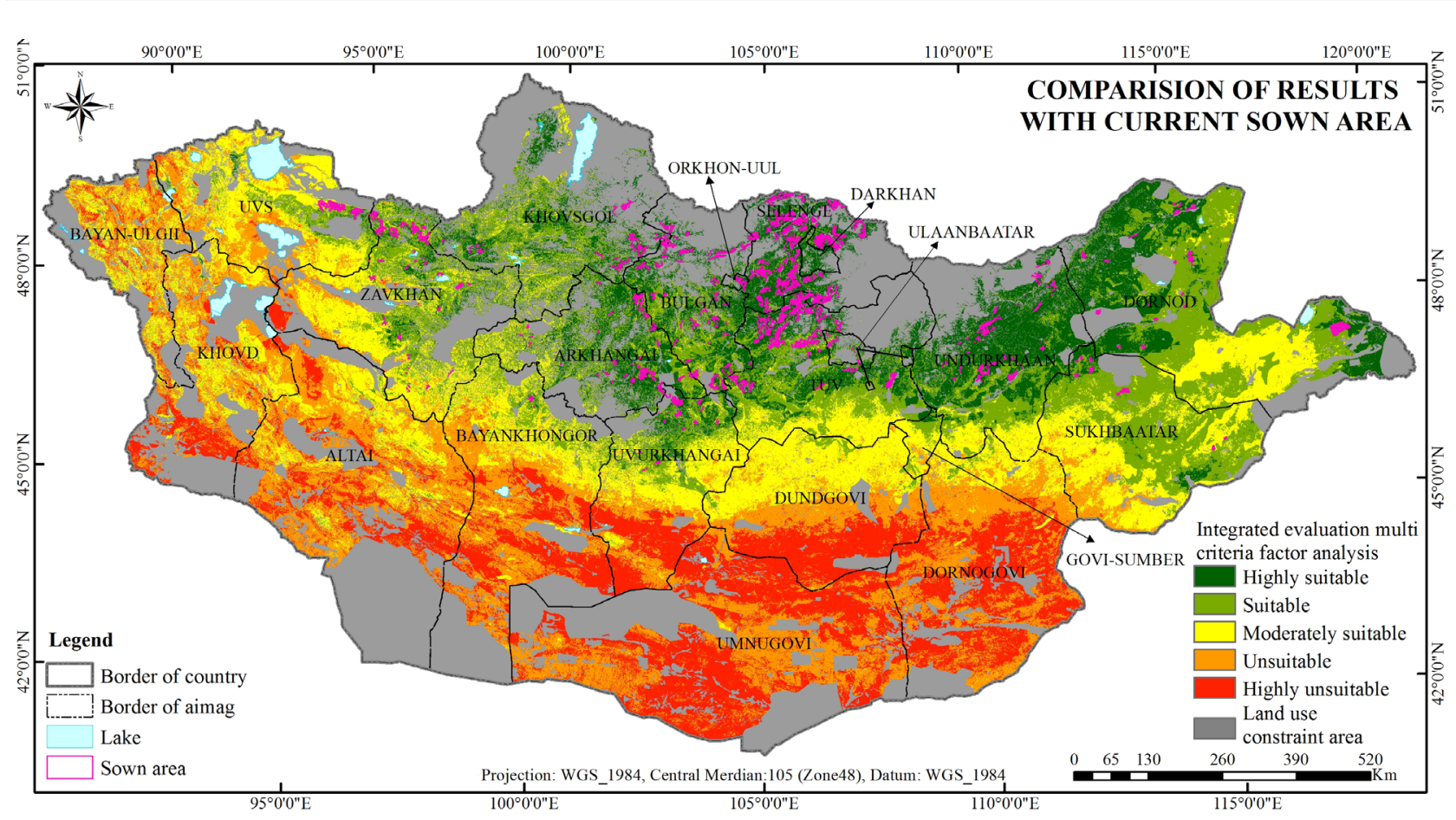

Figure 7. Evaluation validation.

Table 8. Comparison of results with sown area.

\begin{tabular}{ccc}
\hline \multirow{2}{*}{ Suitability classification } & \multicolumn{2}{c}{ Comparison of results (\%) } \\
\cline { 2 - 3 } & Preliminary study result & Current study result \\
\hline Highly suitable & 30.0 & 82.4 \\
Suitable & 67.5 & 16.2 \\
Moderately suitable & 1.80 & 1.40 \\
Unsuitable & 0.40 & - \\
Highly unsuitable & 0.00 & - \\
\hline
\end{tabular}

and it allows for the possibility of justifying policy decisions with science.

\section{Acknowledgements}

The authors would like to thank a number of organizations who provided data for this study: The Information and Research Institute of Meteorology, Hydrology and Environment (IRIMHE); The Agency of Administration of Land Affairs, Geodesy \& Cartography; and InjGeoTech LLC. We thank the EURASIA-PACIFIC UNINET/Ernst Mach Scholarship program for financial support. We are grateful to Gerhard Mocza, Markus Immitzer, Martin and Francesco Vuolo who are researchers of the Natural Resources and Life Sciences (BOKU) for their assistance in this research. We thank all colleagues at the Institute of Geography and Geoecology, Mongolian Academy of Sciences who helped in this study.

\section{References}

[1] Gunguudorj, Sh. (2009) Brought Virgin Lands under Cultivation and It Developed 
Independent Agricultural Cropland Sector in Mongolia. Proceeding of the National Conference ATAR-50, Ulaanbaatar, 23 November 2009, 4-19.

[2] National Statistics Office of Mongolia (2016) Total Sown Area Data between 1960-2016 Years. Mongolian Statistical Information Service, Ulaanbaatar.

http://www.1212.mn

[3] National Statistic Committee (2016) Methodology of Estimate of Food Security Statistical Parameters. The Technical Note of Mongolian National Statistic Committee, Ulaanbaatar, 1-25.

http://www.sukhbaatar.nso.mn/uploads/users/16/files/argachlal/cafc3khunsnii_ayul gvi_baidal.pdf

[4] Mongolian Customs (2016) Food Vegetables Import Data between 1995-2016 Years. Statistical Information System, Ulaanbaatar.

http://customs.gov.mn/statistics/

[5] Munkhdulam, O. and Jargaltulga, T. (2016) Agricultural Cropland Suitability Evaluation in Mongolia. The Project Report Land Suitability Evaluation in Mongolia. In: Mygmarjav, M., Ed., Eng-GeoTech LLC and Institute of Geography, Mongolian Academy of Sciences, Ulaanbaatar, 1-134.

[6] Clement, A. (2013) Advances in Remote Sensing of Agriculture: Context Description, Existing Operational Monitoring Systems and Major Information Needs. Remote Sensing, 5, 949-981. http://www.mdpi.com/2072-4292/5/2/949 https://doi.org/10.3390/rs5020949

[7] Clement, A., Jacques, D. and Anja, K. (2008) Smoothing Time Series of Satellite-Derived Vegetation Indices for Global Monitoring of Agricultural Productivity and Food Security. Joint Research Center (JRC) of the European Commission, IPSC, Agriculture Unit, Ispra.

[8] Eastman, J.R., Jin, W., Kyem, A.K. and Toledano, J. (1995) Raster Procedures for Multi-Criteria/Multi-Objective Decisions. Photogrammetric Engineering and Remote Sensing, 61, 539-547.

[9] Deng, F., Li, X., Wang, H., Zhang, M. and Li, R. (2014) GIS-Based Assessment of Land Suitability for Alfalfa Cultivation: A Case Study in the Dry Continental Steppes of Northern China. Spanish Journal of Agricultural Research, 12, 364-375. https://doi.org/10.5424/sjar/2014122-4672

[10] Burrough, P.A. (1992) Development of Intelligent Geographical Information Systems. International Journal of Geographical Information Systems, 6, 1-11. https://doi.org/10.1080/02693799208901891

[11] Prakash, T.N. (2003) Land Suitability Analysis for Agricultural Crops: A Fuzzy Multicriteria Decision Making Approach. International Institute for Geo-Information Science and Earth Observation Enschede, 1-68. http://www.iirs.gov.in/iirs/sites/default/files/StudentThesis/final_thesis_prakash.pdf

[12] Ceballos-Silva, A. and López-Blanco, J. (2003) Delineation of Suitable Areas for Crops using a Multi-Criteria Evaluation Approach and Land Use-Cover Mapping: A Case Study in Central Mexico. Agricultural Systems, 77, 117-136.

[13] Malczewski, J. (1999) GIS and Multicriteria Decision Analysis. John Wiley and Sons, Inc.

[14] Malczewski, J. (2004) GIS-Based Land-Use Suitability Analysis: A Critical Overview. Progress in Planning, 62, 3-65.

[15] Carver, S.J. (1991) Integrating Multi-Criteria Evaluation with Geographic Information Systems. International Journal of Geographical Information Systems, 5, 321-339. https://doi.org/10.1080/02693799108927858 
[16] Banai, R. (1993) Fuzziness in Geographical Information Systems: Contribution from the Analytic Hierarchy Process. International Journal of Geographical Information Science, 7, 315-329. https://doi.org/10.1080/02693799308901964

[17] Eastman, J.R. (1997) Idrisi for Windows, Version 2.0: Tutorial Exercises. Graduate School of Geography-Clark University, Worcester.

[18] Thill, J.C. (2000) Geographic Information Systems for Transportation in Perspective. Transportation Research Part C. Emerging Technologies, 8, 1-6.

[19] Sui, D.Z. (1994) Recent Applications of Neural Networks for Spatial Data Handling. Canadian Journal of Remote Sensing, 20, 368-380. https://doi.org/10.1080/07038992.1994.10874580

[20] Chen, Y., Yu, J., Shahbaz, K. and Xevi, E. (2009) A GIS-Based Sensitivity Analysis of Multi-Criteria Weights. 18th World Images Congress and Modsim 09 International Congress on Modelling and Simulation, Cairns, 13-17 July 2009, 3137-3143. http://mssanz.org.au/modsim09

[21] Dermirel, T., Demirel, N.C. and Kahraman, C. (2009) Fuzzy Analytic Hierarchy Process and Its Application. In: Kahraman, C., Ed., Fuzzy Multi-Criteria Decision Making: Theory and Applications with Recent Developments, 16, 53-84.

[22] Zhang, K. and Achari, G. (2010) Uncertainty Propagation in Environmental Decision Making using Random Sets. Procedia Environmental Sciences, 2, 576-584.

[23] Zarghami, M., Szidarovszky, F. and Ardakanian, R. (2008) A Fuzzy-Stochastic OWA Model for Robust Multi-Criteria Decision Making. Fuzzy Optimization and Decision Making, 7, 1-15.

https:/link.springer.com/article/10.1007\%2Fs10700-007-9021-y?LI=true https://doi.org/10.1007/s10700-007-9021-y

[24] Mosadeghi, R., Warnken, J., Tomlinson, R. and Mirfenderesk, H. (2013) Uncertainty Analysis in the Application of Multi-Criteria Decision-Making Methods in Australian Strategic Environmental Decisions. Journal of Environmental Planning and Management, 56, 1097-1124. https://doi.org/10.1080/09640568.2012.717886

[25] McBratney, A.B. and Odeh, I.A. (1997) Application of Fuzzy Sets in Soil Science: Fuzzy Logic, Fuzzy Measurements, and Fuzzy Decisions. Geoderma, 77, 85-113.

[26] Collins, M.G., Steiner, F.R. and Rushman, M.J. (2001) Land-Use Suitability Analysis in the United States: Historical Development and Promising Technological Achievements. Environmental Management, 25, 611-621. https://doi.org/10.1007/s002670010247

[27] Zadeh, L.A. (1965) Fuzzy Sets. Information and Control, 8, 338-353.

[28] Ligmann-Zielinska, A. (2013) Spatially-Explicit Sensitivity Analysis of an Agent-Based Model of Land Use Change. International Journal of Geographical Information Science, 25, 1764-1781. https://doi.org/10.1080/13658816.2013.782613

[29] Joerin, F., Thériault, M. and Musy, A. (2001) Using GIS and Outranking Multicriteria Analysis for Land-Use Suitability Assessment. International Journal of Geographical Information Science, 15, 153-174. https://doi.org/10.1080/13658810051030487

[30] Malczewski, J. (2006) GIS-Based Multicriteria Decision Analysis: A Survey of the Literature. International Journal of Geographical Information Science, 20, 703-726. https://doi.org/10.1080/13658810600661508

[31] Baja, S., Chapman, D.M. and Dragovich, D. (2006) Spatial Based Compromise Programming for Multiple Criteria Decision Making in Land Use Planning. Environmental Modeling \& Assessment, 12, 171-184. 
https://link.springer.com/article/10.1007\%2Fs10666-006-9059-1?LI=true https://doi.org/10.1007/s10666-006-9059-1

[32] Saaty, T.L. (1980) The Analytic Hierarchy Process. McGraw-Hill, New York.

[33] Wu, F. (1998) SimLand: A Prototype to Simulate Land Conversion through the Integrated GIS and CA with AHP-Derived Transition Rules. Geographical Information Science, 12, 63-82. https://doi.org/10.1080/136588198242012

[34] Saaty, T.L. (2008) Decision Making with the Analytic Hierarchy Process. International Journal of Services Sciences, 1, 83-98. https://doi.org/10.1504/IJSSCI.2008.017590

[35] Chen, Y., Yu, J. and Khan, S. (2010) Spatial Sensitivity Analysis of Multi-Criteria Weights in GIS-Based Land Suitability Evaluation. Environmental Modelling and Software, 25, 1582-1591.

[36] Pascual, R., Rainer, M., David, M. and Hui, C. (2010) Spatially-Explicit Sensitivity Analysis for Conservation Management: Exploring the Influence of Decisions in Invasive Alien Plant Management. Diversity and Distributions, 16, 426-438. https://doi.org/10.1111/j.1472-4642.2010.00659.x

[37] Mutanga, O., Adam, E. and Cho, M.A. (2012) High-Density Biomass Estimation for Wetland Vegetation using Worldview-2 Imagery and Random Forest Regression Algorithm. International Journal of Applied Earth Observation and Geoinformation, 18, 399-406.

[38] Abdi, H. (2007) Partial Least Square Regression: PLS Regression. In: Neil, S., Ed., Encyclopedia of Measurement and Statistics, 1-13. http://www.utd.edu/ Herve/Abdi-PLSR2007-pretty.pdf

[39] Geladi, P. and Kowalski, B.R. (1986) Partial Least-Squares Regression: A Tutorial. Analytica Chimica Acta, 185, 1-17.

[40] Gitelson, A.A., Kaufman, Y.J. and Merzlyak, M.N. (1996) Use of a Green Channel in Remote Sensing of Global Vegetation from EOS-MODIS. Remote Sensing of Environment, 58, 289-298.

[41] Jordan, C.F. (1969) Derivation of Leaf-Area Index from Quality of Light on the Forest Floor. Ecology, 50, 663-666. https://doi.org/10.2307/1936256

[42] Gitelson, A.A. (2005) Remote Estimation of Canopy Chlorophyll Content in Crops. Geophysical Research Letter, 32, L08403. https://doi.org/10.1029/2005GL022688

[43] Rouse, J.W., Haas, R.H., Schell, J.A. and Deering, D.W. (1974) Monitoring Vegetation Systems in the Great Plains with ERTS. NASA, Goddard Space Flight Center $3 d$ ERTS-1 Symposium, Vol. 1, 309-317. https://ntrs.nasa.gov/search.jsp?R=19740022614

[44] Liu, H.Q. and Huete, A.A. (1995) Feedback Based Modification of the NDVI to Minimize Canopy Background and Atmospheric Noise. IEEE Transaction on Geoscience and Remote Sensing, 33, 457-465.

http://ieeexplore.ieee.org/document/370361/ https://doi.org/10.1109/36.377946

[45] Jiang, Z., Huete, A.R., Didan, K. and Miura, T. (2008) Development of a Two-Band Enhanced Vegetation Index without a Blue Band. Remote Sensing of Environment, 112, 3833-3845.

[46] Gitelson, A.A. (2004) Wide Dynamic Range Vegetation Index for Remote Quantification of Biophysical Characteristics of Vegetation. Journal of Plant Physiology, 161, 165-173. https://doi.org/10.1078/0176-1617-01176

[47] Gitelson, A.A., Peng, Y., Masek, J.G., Rundquist, D.C., Verma, S., Suyker, A., Baker, 
J.M., Hatfield, J.L. and Meyers, T. (2012) Remote Estimation of Crop Gross Primary Production with Landsat Data. Remote Sensing of Environment, 121, 404-414.

[48] Qi, J.A., Chehbouni, H.A.R., Kerr, Y.H. and Sorooshian, S.A. (1994) Modified Soil Adjusted Vegetation Index. Remote Sensing of Environment, 48, 119-126.

[49] Gallagher, S.J., Duddy, I.R., Quilt, P.G., Smith, A.J., Wallance, M.W., Holdgate, G.R. and Boult, P.J. (2004) The Use of Foraminiferal Colouration Index (FCI) as a Thermal Indicator and Correlation with Vitrinite Reflectance in the Sherbrook Group, Otway Basin, Victoria. Eastern Australian Basins Symposium II, Adelaide, 5, 643-653. https://www.researchgate.net/profile/Stephen_Gallagher/publication/

[50] Chen, T.-W., Chen, Y.-L. and Chien, S.-Y. (2008) Fast Image Segmentation Based on K-Means Clustering with Histograms in HSV Color Space. 10th Workshop on Multimedia Signal Processing, Cairns, 8-10 October 2008, 322-325.

http://ieeexplore.ieee.org/abstract/document/4665097/

[51] Escadafal, R. and Bacha, S. (1996) Strategy for the Dynamic Study of Desertification. ORSTOM, 19-34. http://www.documentation.ird.fr/hor/fdi:010008392

[52] Huete, A.R. and Escadafal, R. (1991) Assessment of Biophysical Soil Properties through Spectral Decomposition Techniques. Remote Sensing of Environment, 35, 149-159.

[53] Xiao, J., Shenb, Y., Gec, J., Tateishia, R., Tanga, C., Liangd, Y. and Huange, Z. (2006) Evaluating Urban Expansion and Land Use Change in Shijiazhuang, China, by using GIS and Remote Sensing. Landscape and Urban Planning, 75, 69-80.

[54] Gao, B.C. (1996) NDWI-A Normalized Difference Water Index for Remote Sensing of Vegetation Liquid Water from Space. Remote Sensing of Environment, 58, 257-266.

[55] Datt, G., Ravallion, M. and World Bank (1990) Agriculture and Rural Development Department. Regional Disparities, Targeting, and Poverty in India Policy, Research, and External Affairs Working Papers. Agricultural Policies WPS, Vol. 375, 41. http://documents.worldbank.org/curated/en/539051468750540233/pdf/multi0page. pdf

[56] Chen, F., Kissel, D.E., West, L.T. and Adkins, W. (2000) Field-Scale Mapping of Surface Soil Organic Carbon Using Remotely Sensed Imagery. Journal of Soil and Water Conservation, 64, 746-753.

https://dl.sciencesocieties.org/publications/sssaj/abstracts/64/2/746 https://doi.org/10.2136/sssaj2000.642746x

[57] Dwivedi, R.S. (2001) Soil Resource Mapping: A Remote Sensing Perspective. Remote Sensing Reviews, 20, 89-122. https://doi.org/10.1080/02757250109532430

[58] Fox, G.A. and Sabbagh, G.J. (2002) Estimation of Soil Organic Matter from Red and Near-Infrared Remotely Sensed Data Using a Soil Line Euclidean Distance Technique. Soil Science Society of America Journal, 66, 1922-1929. https://doi.org/10.2136/sssaj2002.1922

[59] Seyler, F., Bernoux, M. and Cerri, C.C. (1998) Landsat TM Image Texture and Moisture Variations of the Soil Surface under the Rainforest of the Rondonia State, Brazil. International Journal of Remote Sensing, 19, 1299-1317. https://doi.org/10.1080/014311698215450

[60] Ahmed, Z. and Iqbal, J. (2014) Evaluation of Landsat TM5 Multispectral Data for Automated Mapping of Surface Soil Texture and Organic Matter in GIS. European Journal of Remote Sensing, 47, 557-573. https://doi.org/10.5721/EuJRS20144731

[61] Lakshmi, S.V., Jamesb, J., Soundariya, S., Vishalini, T. and Kasinatha, P. (2015) A Comparison of Soil Texture Distribution and Soil Moisture Mapping of Chennai 
Coast using Landsat ETM+ and IKONOS Data. Aquatic Procedia, 4, 1452-1460.

[62] Slonecker, E.T., Jones, D.K. and Pellerin, B.A. (2015) The New Landsat 8 Potential for Remote Sensing of Colored Dissolved Organic Matter (CDOM). Marine Pollution Bulletin, 107, 518-527.

[63] Kelgenbaeva, K. and Buchroithner, N. (2003) Modeling Soil and Climatic Conditions for Agricultural Suitability Assessment in the Siberian Altai. Proceedings of the 21 st International Cartographic Conference (ICC) Cartographic Renaissance, Durban, 306-315.

http://icaci.org/files/documents/ICC_proceedings/ICC2003/Papers/038.pdf

[64] Vandandorj, S., Munkhjargal, E., Boldgiv, B. and Gantsetseg, B. (2017) Changes in Event Number and Duration of Rain Types over Mongolia from 1981 to 2014. Environmental Earth Sciences, 76, 1-12.

\author{
Abbreviations \\ MCDM (Multi-Criteria Decision Method); \\ AHP (Analytical Hierarchy Process); \\ RF (Random Forest); \\ PLS (Partial Least Squares).
}

\title{
Scientific Research Publishing
}

Submit or recommend next manuscript to SCIRP and we will provide best service for you:

Accepting pre-submission inquiries through Email, Facebook, LinkedIn, Twitter, etc. A wide selection of journals (inclusive of 9 subjects, more than 200 journals)

Providing 24-hour high-quality service

User-friendly online submission system

Fair and swift peer-review system

Efficient typesetting and proofreading procedure

Display of the result of downloads and visits, as well as the number of cited articles

Maximum dissemination of your research work

Submit your manuscript at: http://papersubmission.scirp.org/

Or contact gep@scirp.org 